\title{
GROWING MEDIA FOR ORGANIC TOMATO PLANTLET PRODUCTION.
}

\author{
K. L. Nielsen and K. Thorup-Kristensen \\ Danish Institute of Agricultural Sciences \\ Department of Horticulture, Kirstinebjergvej 10, \\ P.O.Box 102, DK-5792 Aarslev \\ Denmark
}

Keywords: growing media, organic production, plant nutrition, Lycopersicon lycopersicum.

\begin{abstract}
$\underline{\text { Abstract: }}$
The choice of growing media and the strategy of application of organic fertilizers is considered one of the largest challenges for production of organic tomato plantlets for transplanting. We have measured the growth and the ability of young tomato plantlets to extract plant nutrients from an organic growing media. Plants were grown in $0.45 \mathrm{~L}$ pots. Plant nutrition were either entirely based on the mineral nutrients, available from the organic growing media or based on a combination of nutrients from the organic growing media and fertigation with water-soluble organic fertilizers during plantlet production. The first results shows that plant dry weigth and uptake of nitrogen, phosphorus and potassium was reduced in the organic growing media compared to the control, peat based growing media, but the results also indicate a possibility for optimizing the suggested organic growing media in order to increase the nutrient acquisition and utilization efficiency of the plants. Improved organic growing media can supply most of the necessary plant nutrients needed for the plant, limit the need for supplementary fertilisation, and be an alternative to conventional production with inorganic fertilizers.
\end{abstract}

\section{Introduction.}

The release and availability of nutrients, root growth dynamics and nutrient uptake will affect plant growth and yield. The distance is very short between being able to meet the nutrient demands and having excessive nutrient availability and thereby a risk of nutrient leaching losses to the environment or nutrient imbalances or toxicity problems for the plant.

A number of studies of different soil-less substrates have been made (Lamanna et al., 1991; Ku et al., 1998) using compost from different sources. Many of the problems that have been identified have been related to salt problems, structural problems and water capacity problems, all factors that are very critical in an efficient production (Weinhold et al., 1997). An emphasis on obtaining high quality uniform soil-less substrates is essential to enhance the organic production, but this needs to be closely co-ordinated with water and fertilisation techniques, since the organic fertilisers are releasing their nutrients over a longer period, compared to the immediate availability of chemical fertilisers (Berner et al., 1996). The 
choice of growing media and the strategy of application of organic fertilizers is considered one of the largest challenges for production of organic tomato plantlets for transplanting.

An optimal compost should contain enough $\mathrm{N}$ rich materials to supply $\mathrm{N}$ for the plants during the entire production period. $\mathrm{P}$ and $\mathrm{S}$ are build into organic compounds similarly to $\mathrm{N}$, and must be mineralised in the compost before they become available for the plants. Previous results have shown that both $\mathrm{P}$ and $\mathrm{S}$ can be readily mineralised, the mineralisation rate depending on various factors (Dalal, 1979; Till et al., 1978; Enwezor, 1976, Eriksen et al., 1999) where $C / P$ ratio and $C / S$ ratio seem to be of major importance, as the $C / N$ ratio for $N$ mineralisation. On the other hand, $\mathrm{K}, \mathrm{Ca}$ and $\mathrm{Mg}$ is present as ions in the composted material, and do not need mineralisation to become available. $\mathrm{K}$ is not bound in the composted material, and can be regarded as immediately available for other plants (Christensen, 1985). Considering the amounts of various nutrients available in the composted materials, this could lead to excess availability of K compared to other nutrients, and an imbalance between $\mathrm{K}$ supply and $\mathrm{Ca}$ and $\mathrm{Mg}$ supply.

When plants are grown without soil contact, the compost must also secure the supply of micro nutrients. The ability of the growth medium to do this, will depend not only on the total content and release of these nutrients, but at least for some nutrients as $\mathrm{Mn}$ and Fe it will also depend on $\mathrm{pH}$ and redox conditions within the growing medium.

Fluctuations in the availability of nutrients (especially ammonium, potassium and phosphorus) during the production period can be expected due to ongoing composting processes (Jensen et al., 1998). In order to reduce the risk of nutrient fluctuations it is important to use stable and mature compost. The availability of specific nutrients will at times be very high and can depress plant growth and/or fruit quality. To avoid high concentrations of ammonium and other nutrient elements in the root environment a nutrient buffer can be incorporated into the medium, for instance clay minerals such as zeolite or glauconite.

It was the aim of the experiment to descibe and compare the growth and nutrient uptake of plants grown in an organic composted peat/manure based growing media to plants grown in a conventional peat based growing media irrigated with a standard nutrient solution. Secondly, it was the aim to evaluate the possibility for optimizing the suggested growing media in order to increase the nutrient availability in the growing media and acquisition efficiency of the plants in order to limit the need for supplementary fertilisation.

2. Materials and methods.

\subsection{Plant material.}

Seeds of tomato (Lycopersicon lycopersicum 'Aromata') were sowed in plastic pots $(\varnothing=11 \mathrm{~cm}$, volume $0.45 \mathrm{~L}$ ) containing either peat based growing media (Pindstup 2, Pindstrup Mosebrug A/S, Denmark) or an organic composted peat/manure based growing media (Alternativjord, Svalöf Weibull Torv AB, Sweden). The organic composted peat/manure based growing media consisted of peat composted with cow manure for 2 years, then added chicken manure and composted for an additional year and finally mixed with peat in the ratio $40 \%$ compost to $60 \%$ peat. 


\subsection{Irrigation water.}

The peat based growing media was irrigated with a standard nutrient solution (Peat + std.; Table 1) and the organic growing media was either irrigated with rain water (Alt.- fert.; Table 1$)$ or with a water soluble organic fertilizer (0.25\% BioRika, Neudorff GmbH KG, Emmerthal, Germany, Alt. + fert.; Table 1) giving a total of three treatments. Each treatment was replicated three times in a randomized block design and the experiment was carried out on individually controlled ebb-flood benches. The plants were grown in a greenhouse at Research Centre Aarlev, Denmark, in April 2001, with controlled climate at a temperature of $20-25^{\circ} \mathrm{C}$. No artificial ligthing or $\mathrm{CO}_{2}$ was added. The $\mathrm{pH}$ of irrigation water was not significantly different when comparing the standard nutrient solution with rain water (Table 1), but was significantly higher in the water soluble organic fertilizer. Although the concentration of $\mathrm{PO}_{4}-\mathrm{P}$ and $\mathrm{K}$ was much higher in the water soluble organic fertilizer, the electrical conductivity was lower in this nutrient solution compared to the standard solution. This was due to the lower concentrations of $\mathrm{NO}_{3}-\mathrm{N}$, magnesium, calcium and sulphate measured in the solution with water soluble organic fertilizer. The content of iron, manganese and cupper was also lower in this nutrient solution, but probably not affecting the electrical conductivity significantly.

Table 1. $\mathrm{pH}$, electrical conductivity $\left(\mathrm{EC} ; \mathrm{mS} \mathrm{cm}^{-1}\right)$ and nutrient composition of irrigation water (Irrigation water) $\left(\mathrm{mg} \mathrm{L}^{-1}\right)$ and initial $\mathrm{pH}, \mathrm{EC}$, and nutrient availability (Growing media; day 0 ) and $\mathrm{pH}$, $\mathrm{EC}$, and nutrient availability at the end of production (Growing media; day 38 ) in growing media (mg plant $\left.{ }^{-1}\right)$. The peat based growing media was irrigated with a standard nutrient soultion (Peat + std.). The organic growing media was either irrigated with rain water (Alt.-fert.) or with a water soluble organic fertilizer (Alt. + fert.).

\begin{tabular}{|c|c|c|c|c|c|c|c|c|}
\hline & \multicolumn{3}{|c|}{ Irrigation water } & \multicolumn{2}{|c|}{ Growing media; day 0} & \multicolumn{3}{|c|}{ Growing media; day 38} \\
\hline & + std. & - fert. & + fert. & Peat & Alt. & $\begin{array}{r}\text { Peat } \\
+ \text { std. }\end{array}$ & $\begin{array}{c}\text { Alt. } \\
\text { - fert. }\end{array}$ & $\begin{array}{c}\text { Alt. } \\
+ \text { fert. }\end{array}$ \\
\hline $\mathrm{pH}$ & 5.4 & 5.6 & 7 & 6.1 & 5.6 & 6.0 & 5.1 & 6.0 \\
\hline EC & 1.77 & 0.35 & 1.31 & 3.0 & 5.7 & 4.8 & 5.1 & 6.6 \\
\hline NO3-N & 120 & 1 & 24 & 68 & 154 & 123 & 122 & 147 \\
\hline PO4-P & 35 & 0 & 47 & 71 & 44 & 95 & 27 & 75 \\
\hline $\mathrm{K}$ & 208 & 1 & 317 & 114 & 230 & 170 & 87 & 614 \\
\hline $\mathrm{Mg}$ & 39 & 1 & 5 & - & - & - & - & - \\
\hline $\mathrm{Ca}$ & 98 & 21 & 15 & - & - & - & - & - \\
\hline $\mathrm{Na}$ & 14 & 3 & 52 & - & - & - & - & - \\
\hline $\mathrm{Cl}$ & 29 & 5 & 61 & - & - & - & - & - \\
\hline $\mathrm{SO} 4$ & 69 & 3 & 41 & - & - & - & - & - \\
\hline $\mathrm{Fe}$ & 1.7 & 0 & 0.39 & - & - & - & - & - \\
\hline $\mathrm{Mn}$ & 1.56 & 0.03 & 0.09 & - & - & - & - & - \\
\hline B & 0.18 & 0.11 & & - & - & - & - & - \\
\hline $\mathrm{Cu}$ & 0.09 & 0.005 & 0.02 & - & - & - & - & - \\
\hline $\mathrm{Zn}$ & 0.42 & 0.25 & 0.58 & - & - & - & - & - \\
\hline
\end{tabular}

2.3. Plant and growing media analysis.

Samples of the growing media, taken prior to sowing of the tomatoes and 38 days after sowing, was extracted with diluted acetic acid and analyzed for plant available nitrate, 
phosphate and potassium $\left(\mathrm{NO}_{3}-\mathrm{N}, \mathrm{PO}_{4}-\mathrm{P}\right.$ and $\mathrm{K}$; Table 1$)$ as well as electrical conductivity (EC) and $\mathrm{pH}$. Destructive plant samples for fresh and dry weight measurements were taken $18,25,32$ and 38 days after sowing (Figure 1), and at 38 days after sowing samples were analysed for plant content of nitrogen $(\mathrm{N})$, phosphorus $(\mathrm{P})$ and potassium (Figure 2).

3. Results.

\subsection{Growing media.}

Compared to the peat based growing media the organic peat/manure based growing media contained more plant available nitrate and potassium, but less phosphate (Table 1; Growing media day 0 ). In addition to relatively high nitrate levels the organic peat/manure based growing media contained high levels of ammonium $\left(\mathrm{NH}_{4}-\mathrm{N}\right)$ at the time of sowing $\left(191 \mathrm{mg} \mathrm{L}^{-1}\right)$. The $\mathrm{pH}$ was higher in the peat based growing media and the electrical conductivity in the media was lower before sowing of the tomatoes. At 38 days after sowing the nitrate, phosphate and potassium availability of the peat based growing media had increased (Table 1; Growing media day 38). We observed a decline in nutrient availability in the organic peat/manure based growing media that had only received rain water. The most significant decline was of potassium, whereas the decline in nitrate was much less and the availability was comparable to the level found in the peat based substrate. The organic peat/manure based growing media that was irrigated with the water-soluble organic fertilizer had four times higher potassium level compared to peat based growing media irrigated with a standard nutrient solution. This high availability of potassium and higher levels of sodium and chloride in the irrigation water led to significantly higher EC in this media over time.

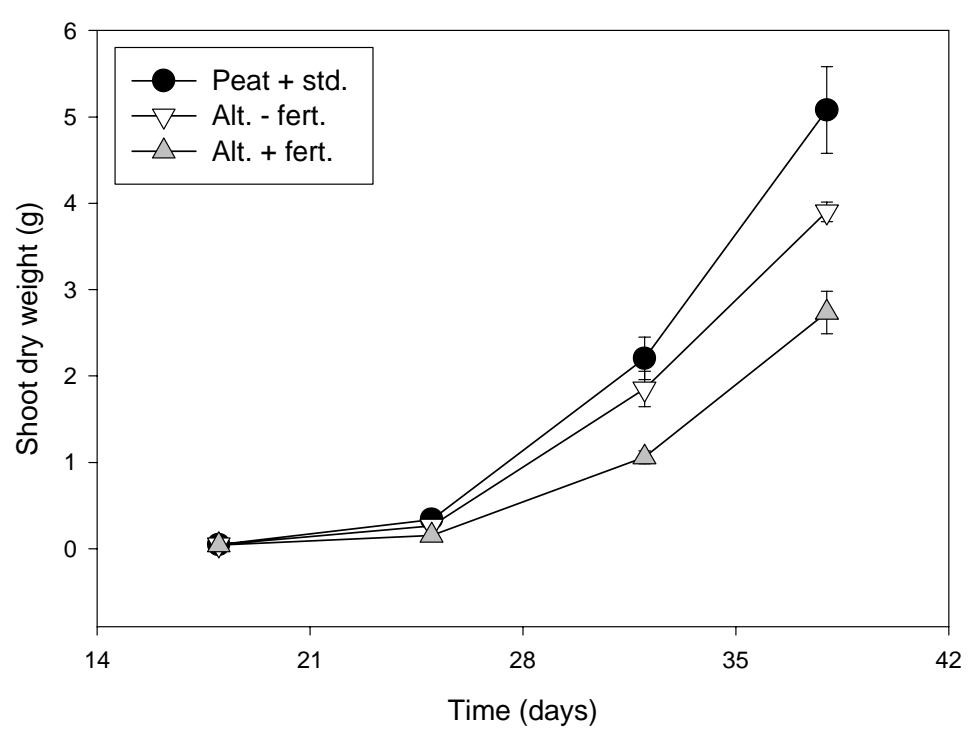

Figure 1. Effect of growing media and fertigation on shoot dry weight of tomato plantlets over time. The standard growing media was irrigated with a standard nutrient solution (Peat + std.). The organic growing media was either irrigated with rain water (Alt.- fert.) or with a water soluble organic fertilizer (Alt. + fert.). Data shown are mean \pm standard error of the mean $(n=3)$. 


\subsection{Plant growth}

Plant DW increased over time for all treatments and the quality of the tomato plantlets were acceptable and comparable. The shoot dry weight of the plants grown in organic peat/manure based growing media and irrigated with rain water was reduced by approximately $25 \%$ and plants irrigated with water soluble organic fertilizer was reduced by approximately $50 \%$ compared to plants grown in peat based growing media and irrigated with standard nutrient solution (Figure 1). The dry weight percentage of the plants grown in organic peat/manure based growing media and irrigated with rain water was $12.4 \%$ and plants irrigated with water soluble organic fertilizer was $9.4 \%$ compared to the $8.3 \%$ of the plants grown in peat based growing media and irrigated with standard nutrient solution.

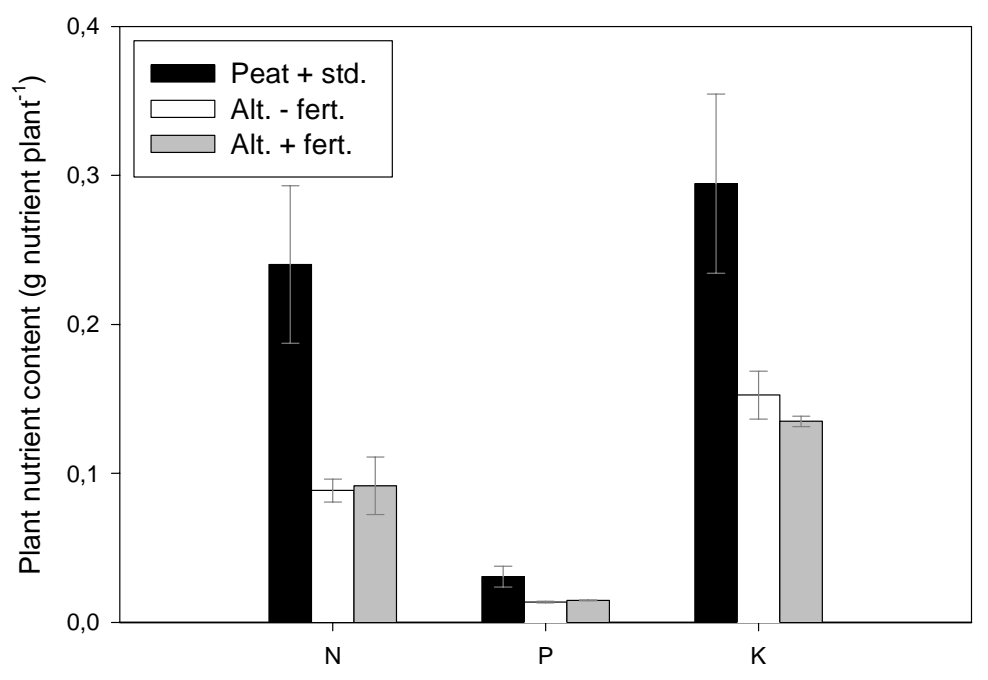

Figure 2. Effect of growing media and fertigation on plant nutrient content of tomato plantlets measured 38 days after sowing. The standard growing media was irrigated with a standard nutrient solution (Peat + std.). The organic growing media was either irrigated with rain water (Alt.fert.) or with a water soluble organic fertilizer (Alt. + fert.). Data shown are mean \pm standard error of the mean $(n=3)$.

\subsection{Nutrient acquisition}

The nutrient content of the plants was significantly affected by the growing media. Plants grown in organic peat/manure based growing media contained significantly less total $\mathrm{N}(38 \%)$, total P (47\%), and total K (49\%) compared to plants grown in peat based growing media (Figure 2). There were no significant differences when comparing the contrasting fertigation treatments of plants grown in organic peat/manure based growing media on the total plant nutrient content, but the concentration in the tissue was significantly higher in plants irrigated with water soluble organic fertilizer due to their lower dry weigth.

\section{Discussion}


Although the content of $\mathrm{PO}_{4}-\mathrm{P}$ and $\mathrm{K}$ was higher in the irrigation water containing a water soluble organic fertilizer (Alt. + fert.), this did not lead to higher total uptake in the plant. Since these plants had significantly lower shoot dry weight, the concentration of total $\mathrm{P}$ and $\mathrm{K}$ in the tissue was higher. The high levels of especially $\mathrm{K}$, sodium and chloride and the higher electrical conductivity of the organic peat/manure based growing media irrigated with water soluble organic fertilizer (Alt. + fert.), can be the cause of the severe reduction in plant dry weight of the plants grown in this treatment. Since K is not bound in the plant material, and can be regarded as immediately available for other plants (Christensen, 1985) and considering the possible imbalance between $\mathrm{K}$ supply and $\mathrm{Ca}$ and $\mathrm{Mg}$ supply, great caution should be used when fertigating the plants with water soluble organic fertilizer (Alt. + fert.) with a high content of $\mathrm{K}$. The decline in $\mathrm{K}$ availability over time in the organic peat/manure based growing media irrigated with rain water (Table 1) indicates that it might have been advantageous to add smaller amounts of or fewer irrigations with the water soluble organic fertilizer, in order to maintain the initial level in the growing media..

The lack of difference in total uptake of $\mathrm{P}$ and $\mathrm{K}$ between the contrasting fertigation treatments of plants grown in organic peat/manure based growing media indicate that the growth of these plants were not limited by the availability of these nutrients. Addition of the water soluble organic fertilizer (Alt. + fert.), did not enhance the growth rate of the plants, but merely led to increasing electrical conductivity and no noteworthy increase in $\mathrm{NO}_{3}-\mathrm{N}$ availability.

Although the $\mathrm{NO}_{3}-\mathrm{N}$ content in the growing media was initially higher in the organic peat/manure based growing media and at a comparable level to the peat based growing media at 38 days after sowing the total $\mathrm{N}$ uptake of the plants were significantly lower compared to plants grown in peat based growing media. The much lower total $\mathrm{N}$ and $\mathrm{P}$ content and the increased dry weigth percentage of the plants grown in the organic peat/manure based growing media compared to the peat based growing media, regardless of fertigation treatment, indicate that the reduced shoot dry weight and growth rate of these plants are influenced by the $\mathrm{N}$ and /or $\mathrm{P}$ availability over time. Growth inhibition due to ammonium nutrition is normally closely related to decreased growing media $\mathrm{pH}$ (Findenegg et al., 1982). We did not observe a significant drop in the growing media $\mathrm{pH}$ in this experiment (Table 1). A temporary depletions of the $\mathrm{NO}_{3}-\mathrm{N}$ sources due to biological immobilization as suggested by Smith et al. (1989) does not seem realistic due to the long composting period prior to the experiment ( 3 years), but high ratios of $\mathrm{NH}_{4}-\mathrm{N}$ to $\mathrm{NO}_{3}-\mathrm{N}$ as measured in the organic peat/manure based growing media are known to reduce dry matter production in tomatoes (Ali et al., 1994).

The plants grown in organic peat/manure based growing media and irrigated with rain water, thus dependent on the nutrients available in the growing media or mineralized from the growing media, were able to extract $88 \mathrm{mg} \mathrm{N}, 13 \mathrm{mg} \mathrm{P}$, and $152 \mathrm{mg} \mathrm{K}$ from the growing media (Figure 1). The demand for $\mathrm{N}$ is increasing over time as the daily biomass gain increases. Considerable uptake of $\mathrm{NH}_{4}-\mathrm{N}$ or net $\mathrm{N}$-mineralisation or leaching of $\mathrm{NO}_{3}-\mathrm{N}$ is occuring since the amount of nitrogen taken up by the plant $(88 \mathrm{mg} \mathrm{N})$ and remaining $\mathrm{NO}_{3}-\mathrm{N}$ in the growing media $(122 \mathrm{mg} \mathrm{NO}-\mathrm{N})$ exceeds the amount of $\mathrm{NO}_{3}-\mathrm{N}$ available initially (154 mg $\mathrm{NO}_{3}-\mathrm{N}$ ). Net mineralisation of $\mathrm{PO}_{4}-\mathrm{P}$ does not exceed $\mathrm{PO}_{4}-\mathrm{P}$ leaching, since the amount of $\mathrm{P}$ taken up by the plant $(14 \mathrm{mg} \mathrm{P})$ and remaining $\mathrm{PO}_{4}-\mathrm{P}$ in the growing media $\left(27 \mathrm{mg} \mathrm{PO}_{4}-\right.$ 
$\mathrm{P}$ ) is equivalent to the amount of $\mathrm{PO}_{4}-\mathrm{P}$ available initially $\left(44 \mathrm{mg} \mathrm{PO}_{4}-\mathrm{P}\right)$. All the $\mathrm{K}$ is available for the plant, as indicated by the sum of the amounts taken up by the plant (152 $\mathrm{mg}$ $\mathrm{K})$ and remaining in the growing media at the end of the experiment $(87 \mathrm{mg} \mathrm{K})$, is almost identical to the amount available initially ( $230 \mathrm{mg} \mathrm{K}$ ). Based on the measurements from this experiment we do not have data to support a discussion on plant acquisition and mineralisation of nutrients from the other two treatments.

The first results points out the need for optimizing the tested organic growing media in order to increase the nutrient acquisition and utilization efficiency of the plants. The results also allow the conclusion that improved organic growing media can supply most of the necessary plant nutrients needed for the plant, thus limiting the need for supplementary fertilisation and being an alternative to conventional production with inorganic fertilizers.

\section{Acknowledgements}

The authors wish to thank Finn Kristiansen for technical assistance. This research was finacially supported by Bara Mineraler AB, Sweden and Svalöf Weibull AB, Sweden and The Directorate for Food, Fisheries and Agro Business under the Danish Ministry of Food, Agriculture and Fisheries, through the projects; "Organic potted plants - development of a platform for production based on marked analysis and plant production experiments with alternative growing medias and organic nutrition" and Research Programme in Organic Farming 2000-2005 "Organic production of cucumber and tomato grown in composted plant material from field crops".

\section{6. $\underline{\text { References }}$}

Ali I.A., Kafkafi U., Sugimoto Y., and Inanaga S. 1994. Response of sand-grown tomato supplied with varying ratios of nitrate/ammonium to constant and variable root temperatures. Journal of Plant Nutrition 17, 2001-2024.

Berner A., Wullschleger J., and Alföldi, T. (1996). Estimation of N-release and Nmineralisation of Garden Waste Compost by the Mean of Easily Analysed Parameters. European Commission International Symposium: The Science of Composting. S. 10781082. Ed.:, Chapman \& Hall, Glasgow.

Christensen B.T. 1985. Wheat and barley straw decomposition under field conditions: effect of soil type and plant cover on weight loss, nitrogen and potassium content. Soil Biol. Biochem. 17, 691-697.

Dalal R.C. 1979. Mineralization of Carbon and Phosphorus from Carbon-14 and Phosphorus32 Labelled Plant Material Added to Soil. Soil Science Society of America Journal 43, 913-916.

Enwezor W.O. 1976. The mineralization of nitrogen and phosphorus in organic materials of varying C:N and C:P ratios. Plant and Soil 44, 237-240.

Eriksen J., Askegaard M., Olesen J.E., and Thorup-Kristensen K. 1999. The sulphur balance of organic crop rotations in Denmark. In "Designing and testing crop rotations for organic farming” (Eds. Olesen, J.E., Eltun, R., Gooding, M.J., Jensen, E.S. and Köpke, U.) DARCOF Report no. 1. 
Findenegg G.R., Salihu M, and Ali N.A. 1982. Internal self-regulation of H+-ion concentration in acid damaged and healthy plants of Sorghum bicolor (L.) Moench. In "Proceedings of the Ninth International Plant Nutrition Colloquium, Warwich, England" (Ed. A. Scaife) pp. 174-179. Commonw. Agric. Bur., Farnham Royal, Bucks.

Jensen, H.E.K. and Leth M. 1998. Forskning i kompost som voksemedie. Gartnertidende $114,10-11$.

Ku C.S.M, Bouwkamp J.C., and Gouin F.R.1998. Effects of compost source and timing of fertigation initiation on growth of potted poinsettia. Compost Science and Utilization 6 , 57-66.

Lamanna D. and D'Angelo G. 1991. Compost-based media as alternative to peat on ten pot ornamentals. Acta Horticulturae 294, 125-129.

Smith S.R. and Hadley P. 1989. A comparison of organic and inorganic fertilizers: their nitrate- $\mathrm{N}$ and ammonium- $\mathrm{N}$ release characteristics and effects on the growth response of lettuce (Lactuca sativa L. cv. Fortune). Plant and Soil 115, 135-144.

Till A.R. and Blair G.J. 1978. The Utilization by Grass of Sulphur and Phosphorus from Clover Litter. Aust.J.Agric.Res. 29, 235-242.

Weinhold F and Roeber RU, 1997. Tolerance of ornamental plants to salt, sodium and chloride in potting substrates containing compost made of separately collected organic residues. Acta Horticulturae 450, 221-228. 